Archaeological Journal

\title{
Grantham Parish Church
}

\section{A. Hamilton Thompson M.A.}

To cite this article: A. Hamilton Thompson M.A. (1909) Grantham Parish Church, Archaeological Journal, 66:1, 401-406, DOI: 10.1080/00665983.1909.10853119

To link to this article: http://dx.doi.org/10.1080/00665983.1909.10853119

曲 Published online: 17 Jul 2014.

Submit your article to this journal 중

III Article views: 2

Q View related articles $₫$ 


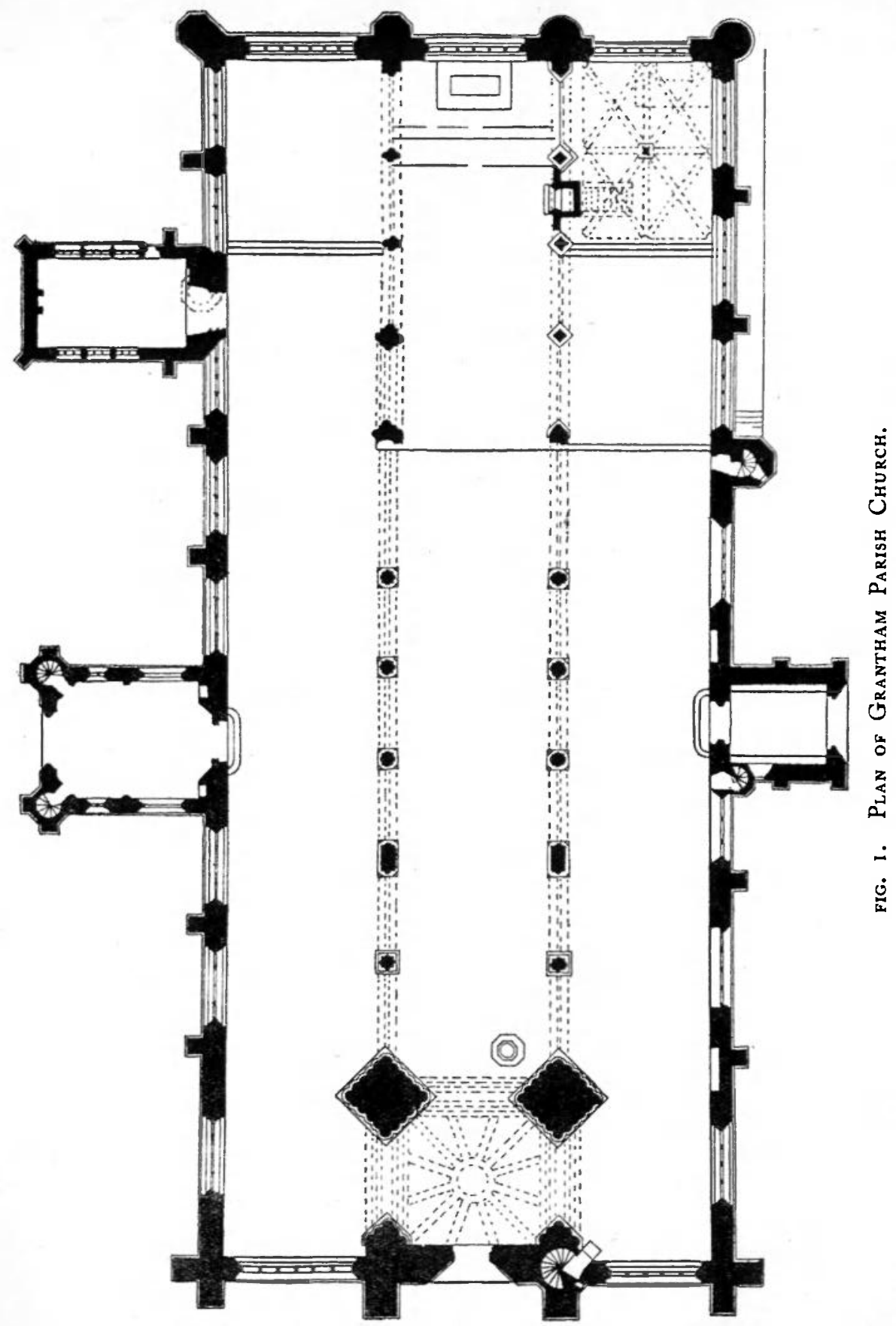




\section{GRANTHAM PARISH CHURCH. ${ }^{1}$}

\section{By A. Hamilton Thompson, M.A.}

As will be seen from the accompanying plan the church of St Wulfran is a simple parallelogram, consisting of a continuous nave and chancel with north and south aisles and engaged western tower and spire: from the north aisle of the chancel projects a small rectangular chapel; there are also north and south porches, while beneath the south aisle of the chancel is a vaulted crypt, divided into two parts by a transverse wall.

The stages of the growth of the building are as follows:

(I) The foundations of what were apparently the walls of the nave of an aisleless church were uncovered during Sir Gilbert Scott's restoration of the fabric. These walls lay just outside the line of the present arcades between the nave and aisles, and did not extend westward of the fourth bay, counting from the east, formed by these arcades. Some part of the masonry of the chancel walls appears to be of twelfth-centurytheor err aarlier character; and a number of stones in the wall below the east window have characteristic Norman tooling. The plan and dimensions of the twelfth-century chancel are very doubtful ; and it is possible that a rebuilding, in which old materials were re-used, may have taken place as part of the enlargement next noticed No traces of a chancel arch are left.

(2) About II 80 aisles, probably much narrower than the present aisles, and covered with lean-to roofs, were added to the nave. The three clustered columns on each side of the eastern part of the nave, with their western responds on either side, belong to the arcades by which the new aisles were now connected with the nave, the responds marking the western limit of the building. The eastern responds were cut away at a later date. The arches above the columns were rounded: the springing of some of them, utilised for the lofty arches which superseded them, is still visible. Above the arches were round-headed clerestory windows, most of which can still be traced. These were blocked when the pointed arches below were built. The columns consist of four attached cylindrical shafts, with smaller shafts, banded round the middle, in the angles of the quatrefoil formed by this plan. The bases are stepped, and the usual hollow moulding of the period is very slightly indicated. The abaci of the main shafts are rectangular, but the connections between them, above the smaller shafts, are rounded. All the capitals in the north arcade of this period are sculptured, a distinct development towards carved foliage being noticeable from west to east. The development advances in the one carved capital on the south side : the sculpture of this arcade was apparently never completed. In some of the capitals the more delicate details have been greatly injured by the galleries which, till the middle of the nineteenth century, stood in this portion of the church.

1 This account of the church was given before the Institute at Grantham, 29th July, I 909 , see page 375 . 
(3) After I250 enlargement and rebuilding went on upon a large scale, probably for some forty to fifty years. This work may be divided into the following parts: (a) The building of the tower and spire, probably the central idea of the enlargement. (Newark church, by about 1230, had acquired its western tower, which, by an after-thought of the builders, was so constructed as to be engaged within aisles.) (b) The junction of the tower, built on a site much to the east of the west end of the earlier church, with the existing nave. ( $c$ ) The addition of aisles to the elongated nave, engaging the tower.

These works formed part of one large scheme, and the actual order in which they were carried out is not very easy to trace. The great clustered piers of the tower were connected by arcades of two bays on either side with the earlier arcades. Part of the wall west of the twelfth-century responds was left untouched, and the new responds were built up against its western side. The division between the earlier and later portions of the nave is thus very definitely marked. The plan of the older columns was adopted, with modifications, for the newer. The main shafts are somewhat larger in plan; the angle-shafts are so closely attached as to be little more than rounded swellings, and have no central band; the capitals have rounded abaci, and their bells, rather long in shape, are moulded with a series of convex mouldings, without sculptured foliage; and the bases, standing on stepped plinths, also have the convex mouldings characteristic of the later part of the thirteenth century. The new arches were pointed; and, to match these, pointed arches were substituted for the rounded arches of the older arcade. As has been said, the springing-stones of some of the old arches were kept in place and utilised for the new arches, which, owing to the narrowness of the bays, took a very acutely pointed form. The old clerestory was thus broken into and blocked up : a clerestory formed no part of the new elevation.

The vast piers of the tower are composed of clusters of closely attached shafts, whose bases correspond in moulding with those of the later columns of the nave. From capitals at different levels spring the lofty eastern arch of the tower, and the much lower arches opening into the aisles. The lowest stage is ceiled above the level of the crown of the tower arch with an octopartite vault, whose broad, flat ribs terminate in a rib surrounding a central hole, circular in form, through which the bell-ropes passed. There is a doorway in the lower part of the west wall, the outer arch of which is elaborately moulded, with a series of shafts in the jambs. The jambs, however, have been much restored, and the level of the threshold altered. Above the doorway is the west window of four lights, the tracery of which is formed by the intersection of the mullions in the head. Arch, jambs, and mullions are lavishly ornamented with ball-flower, which also occurs in the arch of the west doorway.

The north aisle, which is rather broader than the nave, was planned on a magnificent scale. It seems probable that the thirteenth century alterations were begun with the setting-out of the tower and this aisle, the westernmost bay of which corresponds to the broad space occupied by the ground floor of the tower and its piers. The remaining six bays, however, the third of which from the west is occupied by the north doorway, are broader than the bays of the nave arcade: the doorway is opposite a column, and does not correspond to a space between two columns; and the easternmost bay overlaps 
the western part of the chancel. In all probability, then, an entire rebuilding of the church on a lengthened plan was contemplated, but eventually abandoned in favour of the cheaper method already described; and, in addition to the two new arches at the west end of the nave, an arch was pierced in the chancel wall, communicating with the chapel at the east end of the new aisle. The magnificent north doorway with its covering porch was probably completed at an early period in the progress of the work. The windows in the north wall of the aisle are all of four lights, with tracery formed of cusped circles: the west window is of six lights. From the likeness of the tracery of this window to that of the eight-light east window of Lincoln, and the general likeness of the side-windows to those of the chapter-house at Salisbury, the date of the completion of this aisle may be fixed with some certainty at about 1280 . The church of Grantham had been, at any rate since the reign of Henry I, a prebendal church of Salisbury, divided into two medieties; and it is within the bounds of probability that Salisbury exercised some architectural influence upon its fabric. It is necessary, however, to add that the tower and spire were from the beginning suggested by the as yet incomplete design at Newark; and the spire was finished probably before the eventual design of that at Salisbury had been settled on.

It seems likely that the north aisle was finished and connected with the body of the church before the tower was proceeded with. The piers and arches had already been built, but the details of the west doorway and window indicate that this space was not filled in till quite the end of the thirteenth century. The upper stages of the tower seem to hint at a change of plan as the work proceeded: the original elevation was now probably heightened by an upper stage, with very long double two-light belfry windows in each face, each pair being within a single enclosing arch, and divided by a bold vertical mullion. The wall-space between these windows and the anglebuttresses was ornamented with niches containing figures of saints. This stage seems to have been an afterthought added to a stage with two windows in each face, which may have formed the belfry story in the original design. The crocketed spire, with broaches at the angles, rises from within a parapet: the angle-buttresses are finished off with bold pinnacles; but the south-west buttress, which contains the staircase, is of much greater projection than the others, and, from certain aspects, forms a rather unpleasant feature in the design.

(4) The south aisle, which is of nearly the same breadth as the nave, was no doubt contemplated at the same time as the north aisle. Little, however, was done to it till the beginning of the fourteenth century; and then, doubtless owing to the expense lavished on the tower and spire, the design was executed in a much less imposing manner. The spacing, as far as the south door, is similar to that of the north aisle, and the south doorway and north doorway are exactly opposite each other; but as, by this time, the elaborate scheme of rebuilding and lengthening the church had been abandoned, the new work finished parallel with the east end of the nave arcade, and did not overlap the chancel. The masonry of the south aisle is inferior to the beautiful ashlaring of the north; and, instead of a new doorway and porch, the old early thirteenth-century doorway, itself an addition to the earlier and narrower aisle, was removed to the new wall, and the outer doorway, at any rate, of a thirteenth-century porch, re-used in the new porch. The large windows 
of this aisle have been much restored : one has been superseded by a window of Perpendicular character, and the large west window seems to have been reconstructed entirely by Salvin about 1854, in place of a seventeenth- or eighteenth-century window with gridiron tracery; but the original tracery of the side-windows was formed by mullions crossing in the head and cusped.

(5) An interval in the work seems to have taken place from about $\mathrm{I} 320$ to I350. In the meantime, several chantries were founded within the building. The position of these is impossible to fix definitely; but the two beautiful fourteenth-century tombs of one of the Haryngton family and of Richard Salteby and his wife, in the south wall, may mark the approximate site of two. Another at the east end of the north aisle may have been moved a bay westwards, when the Corpus Christi chapel was built in the fifteenth century. In the earlier part of the fourteenth century, however, two important additions of this kind took place. An upper chamber to the north porch was built, which involved the northward lengthening of the porch and the vaulting of its lower stage. The addition of vaulting ruthlessly mutilated the canopy of the doorway. It is possible that the lengthened porch was met on the north by the original boundary of the churchyard: at any rate, its eastern and western walls are pierced by arches, evidently in order to allow the church processions to pass through. In the northward extension is a holy water stoup, which has sometimes been called the drain of an altar : the exposed position, liable to constant interruption, makes it highly improbable that there ever was such an altar there. The upper stage is approached by a staircase in each of the northern angles of the porch. A small window opening filled with tracery communicated between the upper story and the interior of the church. This, combined with the double staircase, indicates that this upper story was the chapel in which the relics of St. Wulfran and other saints were kept and exposed for the veneration of pilgrims.

About the same time, the eastward extension of the south aisle was contemplated, and the double crypt, extending the whole length of the chancel, was made as a beginning. The eastern and western divisions of this crypt, both vaulted, were approached by small doorways from the churchyard. The eastern division, vaulted from a central column which is curiously out of proportion to the scale of the ribbed vault, contains a stone altar, with a thin slab lying on the back part of its surface, forming a kind of shelf, and a large cavity in front. Here also relics were evidently kept; and perhaps it became the principal relic chapel of the church in the fifteenth century, when a staircase was made to the chancel.

The chapel above, forming the south aisle of the chancel, seems, from the late curvilinear character of the window tracery, and the mouldings of the disproportionately large capitals and bases of the columns in the arcade, which was now cut in the south wall of the chancel, to have been finished about 1350. The chapel is raised above the level of the chancel, to give headway to the vaults of the crypt below. The east window is of six lights, with somewhat inelegant and sprawling tracery. Of the three windows in the south wall, that in the centre has tracery of a rather more simple and earlier character than the rest. This may have been the original east window of the south aisle, removed to this position when the chapel was built. An examination of the mouldings of the next window westward reveals the fact that older stone-work has been re-used here: possibly, while the tracery of 
the older window was inserted within later jambs, the old jambs were used to form a frame for a new window. In the sill of the easternmost of the three windows is a piscina with removable drain.

The rood-screen of the altar in the loft, of which there is a mention in a document in the Patent Rolls, 1 existed by this time. It was of stone : the foundation wall was uncovered at the restoration of 1865 . In order to make it, the eastern responds of the nave arcades were hacked away, and probably the chancel arch, if there was one, was removed. The stone screen does not seem to have been continued across the aisles. When it was built, no doubt, the old east wall of the south aisle was still existing. Subsequently, when the lady chapel was built, the screen across its entrance was probably of wood. A large turret projects outwards from the aisle wall, south of the site of the screen. No opening from this to a loft is now traceable; but it may have communicated with the wooden loft above the lady chapel screen. The original staircase to the loft of the stone screen was probably within the screen itself, as at Southwell and Lincoln.

(6) The conversion of the church into the present aisled rectangle was achieved in the fifteenth century by the lengthening of the north aisle into the Corpus Christi chapel. The old east wall of the north aisle was taken down, and an arcade of three bays, poor and scanty in character, cut in the north wall of the chancel. The new chapel has very large and handsome window; with Perpendicular tracery, the mouldings of which point to the probability that the outer walls were built some time before the junction with the chancel. The date usually assigned to the completion of the chapel is 1486 or 1487 : the name of Richard Foxe, prebendary of South Grantham in Salisbury cathedral, who was the founder of Grantham grammar school and Corpus Christi College, Oxford, and died bishop of Winchester, has been connected with its building, but without foundation. The pelican, which appears with other sacred symbols on the font in the nave, has also been supposed to allude to his devotion to that emblem; but the font, the eight faces of which are carved with reliefs, chiefly of scenes in the early life of our Lord, is probably earlier than his day.

At some time during the fifteenth century new arches were made in the eastern bay of the nave, to give more room and dignity to the screen and loft. This should strictly have been done at an earlier period, and it is difficult to imagine the intermediate stage through which this bay passed, after the making of the stone screen. The new arches are much broader than those immediately west, and spring from a higher point. This springing was managed on the west side without interfering with the existing twelfthcentury column, a small dwarf shaft being built upon the eastern part of the abacus, with a capital from which the new arch sprung. This last alteration must have effectually destroyed any traces of early work which remained in this part of the chancel and nave.

The stone screen, or, rather, porch to the staircase between the chancel and the eastern crypt, is a beautiful example of rather late fifteenth-century work. The raised floor of the lady chapel allowed of its insertion between two of the columns of the south chancel arcade, beyond which it projects slightly into the chancel. A broad and shallow casement moulding, with

I Pat. Rolls, 23 Edw. III, pt. iii, m• 2 (14th Aug. and I6th Oct. 1349). 
four-leaved flowers in it at intervals, is the chief feature of the doorway arch. The surface on either side of the doorway is carved with traceried panelling, and there is a battlemented cresting round the cornice.

(7) In the reign of Henry VIII. the Hall chantry (now the vestry) was built at right angles to the north aisle of the chancel, blocking up a staircase to the roof. The arch of the founder's tomb, from which the table has been removed, forms the present entrance, the small doorway at the side being blocked. The chapel contains indications of an altar, including a rectangular recess in the wall, intended to hold a reredos.

In I 598 a valuable library was bequeathed to the church by the Rev. Francis Trigg, of Welbourn. This was placed, and remains, in the room above the south porch, which was probably remodelled about this time. Another library, now at the west end of the south aisle, was given by Dr. John Newcome, Master of St. John's College, Cambridge, in 1754.

A small clerestory was added to the chancel about the beginning of the reign of Charles I : this unfortunately was removed by Sir Gilbert Scott. The present east window, of a featureless Perpendicular character, may have been inserted at this time : its sill and the lower part of its jambs, however, appear to be of early fourteenth-century date. There is another poor Perpendicular window, of uncertain date, in the south aisle.

During the eighteenth century the top of the spire suffered from lightning twice, and was rebuilt slightly lower than before. The lower stage of the tower was filled up with a bell-ringers' gallery; galleries were added over the aisle at the east end of the church, and the whole of the church east of the north and south doors fenced off from the western part, which was now disused, by a glazed screen. In 1854, the western part of the south aisle was re-roofed and restored by Salvin ; and a general restoration by Sir Gilbert Scott took place from 1866 to 1869 . Since that time, much new furniture has been added to the church, the latest additions to which have been the font cover and organ case, by Mr. Tapper, who also has heightened the altar screen, originally designed by Mr. Bodley, and restored the eastern crypt chapel and Hall's chapel. 